UDC 351.778 .54

Vladimir Vujić

sudija Okružnog suda u Novom Sadu

\title{
SPOR PUNE JURISDIKCIJE POVODOM DODELE STANA*
}

Dilema koja se već duže vreme pojavljuje povodom rešavanja sporova o dodeli stana svodi se na pitanje da li se postupak zaštite prava zaposlenog radnika može obezbeđivati na način koji je do sada bio prisutan. Pitanje spora pune jurisdikcije se nameće samo po sebi, jer poništaj konačne odluke o dodeli stana u suštini ne znači mnogo, s obzirom da se predmet raspodele vraća u radnu organizaciju.

Poći ćemo zbog toga od analize same raspodele i to u onom klasičnom obliku. Presek koji se uzima za dokazivanje situacije po pojedinim kriterijumima iz opšteg akta je momenat zaključenja konkursa, te je do tog roka potrebno pružiti sve dokaze radi pravilnog bodovanja. Sačinjavanje rang liste i prvostepena odluka predstavljaju samo faze u postupku, ukoliko je podnet prigovor zainteresovanog radnika. Tada se, rešavajući po prigovoru, donosi konačna odluka. Član 113. Zakona o radnim odnosima Republike Srbije govori da, radi zaštite pojedinačnih prava iz radnog odnosa, zaposleni može da se obrati arbitraži za radne sporove, nadležnom sudu, sindikatu, inspekcijskim organima i drugim organima u skladu sa Zakonom. U praksi to znači da se postupak može voditi samo protiv konačne odluke, te ukoliko je tužbeni zahtev opredeljen za poništaj rang liste isti se odbacuje kao nedozvoljen, jer je rang lista samo jedna faza u postupku, pa shodno tome i ne uživa pravnu zaštitu. Međutim, sudovi u postupku ispituju zakonitost konačne odluke i pri tome kompletan postupak koji je vođen. Utvrđuje se: da li je blagovremeno podneta dokumentacija, pravilnost bodơvanja, prvostepena odluka, blagovremenost prigovora i konačna odluka. Pri tome, ispituje se i pravilnost bodovanja, te utvrđuje (u obrazloženju) koliko bi koji učesnik konkursa trebalo da ima bodova. Dakle, iako Zakon pominje konačnu odluku, a sve ostalo su sa-

* Rad primljen: 27. X 2000. 
mo faze u postupku, nesumnjivo je da se u postupku pred sudom suštinski ispituje kompletna raspodela. Posebno je pitanje situacije nastale poništajem konačne odluke. Predmet raspodele se tada vraća u fazu zaključenja konkursa (ukoliko i konkurs nije poništen) i ponovo se utvrđuje broj bodova za svakog učesnika konkursa. Ovaj pojednostavljen prikaz već poznatog toka postupka ima značaj da bi se uveli u problem raznih mogućnosti izigravanja prava zaposlenih.

Poništaj konačne odluke ima značaj da za to predviđeni organi rešavaju stambenu situaciju shodno obrazloženju presude, što ih inače ne vezuje. Praksa ukazuje da karikaturalni prikaz gubi značaj, jer se u nekim slučajevima svodi na portret, pa imamo u praksi situaciju da se prilikom novog postupka u obrazloženju konačne odluke kao najjači argument navodi „shodno pravnosnažnoj presudi suda”! Praktično, sud je već presudio a postupak je samo formalan. Ako se tome doda da se neke promenjene okolnosti mogu uzimati u obzir u novoj raspodeli (smrt člana porodičnog domaćinstva, nasledstvo, rešeno stambeno pitanje) dolazi se do apsurdne situacije da ne postoji mehanizam koji bi zaštitio prava zaposlenog. Vispreniji pravnici mogu naći legalno sredstvo za neizvršenje sudskih presuda tako što prilikom odlučivanja neće biti dovoljan broj glasova za donošenje konačne odluke, pa shodno tome neminovno se mora doneti odluka o poništaju konkursa (jer odluke nema). Napominjem da su ovo primeri iz prakse, prisutni u rešavanju konkretnih predmeta. Ova jezička i logička konfuzija nije slučajna, jer dugotrajnost postupka to uslovljava.

Analiza raspodele samo ukazuje na potrebu da ovi sporovi postanu sporovi pune jurisdikcije. Razlozi su brojni a osnovni je, kao što se može videti iz prethodno iznetog, da sudovi u suštini ispituju sve faze postupka, utvrđuju broj bodova, mesto na rang listi i zakonitost konačne odluke. Ako je već to utvrđeno ne postoje razlozi zbog čega ne bi rešili sporni odnos u celini, odnosno doneli presudu koja zamenjuje odluku o dodeli stana. Tvrdi stav da tako nešto pripada isključivo radnoj organizaciji (preduzeću) nema uporište u Zakonu obzirom da već citirani čl. 113. govori samo o zaštiti prava. Ako bi proširili temu na rešavanje stambenih pitanja po svim osnovama, videli bi tek onda apsurdnost situacije. Primera radi, poništaj odluke o raspodeli sredstava za rešavanje stambenih pitanja radnika (sredstva za stambenu izgradnju, adaptaciju, dogradnju itd.) ukazuju da poništaj te odluke praktično ne znači ništa. Autor ovog teksta iz prakse ne zna ni za jedan slučaj da su radnici vratili dobijena sredstva za te namene (a što bi jedino bilo zakonito), ali zna za predmete u kojima se kao tužilac pojavljuje radnik koji je uspeo u sporu, a koji je tražio naknadu štete zbog toga što mu nije dodeljen kredit. Međutim, da ne bi proširivali temu, ostaćemo samo na terenu pitanja postojanja spora pune jurisdikcije kod dodele stana. Svakako je najvažnije da bi sporni odnos ukoliko bi to postali sporovi pune jurisdikcije bio rešen u celini. Sasvim je izvesno, iz napred iznetog, da sudovi ispituju postupak te i pojedine faze pa samim tim proveravajući pravilnost bodovanja u suštini već rešavaju i sporni odnos, a samo obrazloženje presude u najvećem broju slučaje- 
va znači i rešavanje spornog odnosa, te u novom postupku koji se vodi kod firme (preduzeća) faktički se samo po svim fazama ponavlja ono što je već utvrđeno sudskom presudom. Posebno pri tome treba imati u vidu da dugotrajnost samog postupka nesumnjivo ukazuje na potrebu postojanja spora pune jurisdikcije, te da ne postoji gotovo nijedan razlog koji bi ukazivao da sud u takvim slučajevima ne bi mogao da postupa na taj način. 